University of Nebraska - Lincoln

DigitalCommons@University of Nebraska - Lincoln

Biological Systems Engineering: Papers and

Publications

Biological Systems Engineering

4-2012

\title{
First long-term, direct measurements of evapotranspiration and surface water balance in the Nebraska SandHills
}

David P. Billesbach

University of Nebraska-Lincoln, dbillesbach1@unl.edu

Timothy J. Arkebauer

University of Nebraska-Lincoln, tarkebauer1@unl.edu

Follow this and additional works at: https://digitalcommons.unl.edu/biosysengfacpub

Part of the Biological Engineering Commons

Billesbach, David P. and Arkebauer, Timothy J., "First long-term, direct measurements of evapotranspiration and surface water balance in the Nebraska SandHills" (2012). Biological Systems Engineering: Papers and Publications. 217.

https://digitalcommons.unl.edu/biosysengfacpub/217

This Article is brought to you for free and open access by the Biological Systems Engineering at DigitalCommons@University of Nebraska - Lincoln. It has been accepted for inclusion in Biological Systems Engineering: Papers and Publications by an authorized administrator of DigitalCommons@University of Nebraska Lincoln. 


\title{
First long-term, direct measurements of evapotranspiration and surface water balance in the Nebraska SandHills
}

\author{
David P. Billesbach \\ Department of Biological Systems Engineering, University of Nebraska-Lincoln, Lincoln, NE, USA \\ Corresponding author — tel 402 472-7961, email dbillesbach1@unl.edu \\ Timothy J. Arkebauer \\ Department of Agronomy and Horticulture, University of Nebraska-Lincoln, Lincoln, NE, USA; tja@unl.edu
}

\begin{abstract}
The Nebraska SandHills is a vast grassland ecoregion that also serves as the main recharge zone for the High Plains (Ogallala) aquifer. Despite the national importance of this region in supplying irrigation water and supporting the US cattle industry, there have, until now, been no long-term, direct measurements of the components of the surface water balance. We have addressed this issue by installing energy balance/Bowen ratio (EBBR) flux towers in three key ecosystems. We report here the results of 7 years of measurements and interpret them in terms of annual weather variability. Additionally, these data have allowed us to make first-order estimates of the recharge rate to the aquifer. We found that the three ecosystems behave in very different ways, and that, in a first-order estimate, the region provides approximately $115 \pm 20 \mathrm{~mm}$ year $^{-1}$ of recharge to the aquifer over the 2003-2009 period.
\end{abstract}

Keywords: evapotranspiration, energy balance, grasslands, Bowen ratio, aquifer recharge, ecohydrology

\section{Introduction}

From health and sanitation to industry and food production, water is vital to human existence, and access to fresh water has been identified as a major global environmental concern (Clarke, 200o). Understanding the role of water resources in an environment and their relationship to climate is therefore a priority for responsible stewardship. One of the largest fresh water resources in North America and the world is the High Plains (Ogallala) aquifer (USGS, 1997). This vast underground resource underlies $450,000 \mathrm{~km}^{2}$ of eight states (SD, NE, WY, KS, CO, NM, OK, and TX) and is estimated to contain more water than Lake Huron. It is believed that its primary source of recharge is precipitation from the Nebraska SandHills (USGS, 1997; Weeks and Gutentag, 1989; Nativ, 1992; Bleed and Flowerday, 1998).

The Nebraska SandHills ecoregion presents a unique juxtaposition of grassland ecosystems and water regimes (Bleed and Flowerday, 1998; Omernick, 1987; McMahon et al., 2001). This region of grass covered aeolian (wind-blown) sands spans $50,000 \mathrm{~km}^{2}$ or about one quarter of the state of Nebraska. Not only is this the largest grass stabilized sand dune field in the world (Bleed and Flowerday, 1998); it also lies atop the deepest part of the saturated sands and gravels that comprise the High Plains aquifer (USGS, 1997). This unique setting gives rise to an unusual mixture of ecosystems. The region is home to lakes, wetlands, sub-irrigated meadows, dry valley floors, and dunal uplands; all of which co-exist in the overall semiarid climate of the central U.S. Great Plains. Economically, this region supports a significant portion of the Nebraska and U.S. cattle industry, but perhaps more importantly, the underlying High Plains aquifer supplies about $30 \%$ of all the commercial agricultural irrigation water used annually in the United States (USGS, 1997; Weeks and Gutentag, 1989; Nativ, 1992). These facts emphasize the importance of understanding how the component ecosystems function and interact, especially with respect to surface water balance and climate.

Morphologically, the SandHills are made up of large, windsculpted dunal ridge complexes that are separated by interdunal valleys. The ridges may rise $100 \mathrm{~m}$ or more above the associated valley floors and can extend for several kilometers (Bleed and Flowerday, 1998). These dune ridges and their associated sculpting were formed during periods of vegetative destabilization when climatic changes killed the grasses and allowed the underlying sand to move freely. The latest of these mobile periods occurred about 800 to 1000 years ago and was preceded by one at least 3500 years ago (Bleed and Flowerday, 1998). The SandHills are also where the High Plains aquifer lies closest to the land surface; actually intersecting it in places.

The wind-blown topography and the close proximity of the land surface to the aquifer are responsible for the high eco-diversity in this relatively small region. Overall, the region is classified as a mixed-grass prairie with characteristics of both tall and short grass systems. While small lakes and wetlands make up about $2 \%$ of the land surface, $8 \%$ is considered subirrigated 
meadow, $15 \%$ dry valley floors and the remainder is dunal uplands (Rundquist, 1983; Gosselin et al., 2006). The three primary ecosystems (subirrigated meadows, dry valleys and uplands) can be roughly differentiated by their proximity to the water table. Subirrigated meadows generally intersect the water table during at least part of the year and often have soils that are at or near saturation for most of the year. Dry valley floors lie between 1 and $5 \mathrm{~m}$ above the water table, and the vadose (unsaturated) zone near the surface contains significant amounts of available water for much of the year. Dunal uplands are more than $5 \mathrm{~m}$ above the water table and the near surface soils can dry out for significant periods of time between precipitation events. These differing water regimes have given rise to distinct vegetative species communities which have, until now, been the key differentiator between these ecosystems. We propose that because of the species population differences and the different water regimes (i.e. depths to water table) of these ecosystems, each will have a unique evapotranspiration (ET) signature that will be controlled to greater or lesser degrees by precipitation. We further assert that the fine sandy soils (high hydraulic conductivity and low water holding capacity) are also partly responsible for these differences since they may enhance the onset and severity of plant water stress.

In historic times, the SandHills appear to have been relatively robust; having survived the droughts of the 1930 and 1950 os relatively intact (Bleed and Flowerday, 1998). Sridhar et al. (2006b) have suggested that regional wind and precipitation patterns are responsible for the stability of the vegetation cover. While this may be true in the long term, we believe that the historic stability of the region is due to the near-surface water resource of the High Plains aquifer.

With the exception of this work, there has only been one reported study of the interactions between the land surface and the atmosphere, and this only yielded evapotranspiration (ET) data for the growing seasons of two years at a wetland site (Burba et al., 1999). In this project, we sought to address the paucity of data by measuring ET at three ecosystems that are representative of the overall region for multiple years. This allowed us to not only quantify the annual ET in each ecosystem, but to observe the effects of climate on these values and observe their individual and collective contributions to aquifer recharge. We note that a shorter-term analysis (diel to seasonal) of this data set is available in a companion paper (Healey et al., 2012).

\section{Background}

To better understand the relationship between the overlying grassland ecosystems and the aquifer, we begin with the surface water balance relationship. This may be written as:

$$
R=P-E T-Q-\Delta M
$$

where $R$ represents groundwater recharge (or drainage), $P$ is precipitation, ET is evapotranspiration (the sum of surface evaporation and transpiration from the vegetation cover), $Q$ is runoff, and $\Delta M$ is the change in soil water content over the observation period. This relationship is local in nature, and spatial heterogeneity of the driving terms $(P, E T, Q$, and $\Delta M)$ will be reflected in the recharge term, $R$. Of these, $P$ is a direct climatic driver and $E T$ is an environmental response term that embodies the reaction of the vegetation and that of the soil to climate. It is on these two terms that we focused the attention of our measurement efforts.

Because of the coarse, loose texture of the SandHills soils (mostly Valentine fine sands), infiltration rates will be high and little water is available for runoff. We may then consider $Q$ to be negligible over small spatial ( $\sim 1 \mathrm{~km})$ and long temporal (annual) scales (USGS, 1997; Chen et al., 2004). This also has the effect of minimizing the change in soil water content $(\Delta M)$ over annual time scales. While numerous small streams do originate in this region, it is believed that their total out-flow is small, and relatively constant compared with regional precipitation since they are primarily groundwater-fed (Chen et al., 2004). We may therefore, to a good approximation, simplify the water balance relation to:

$$
R \approx P-E T
$$

In other words, the amount of aquifer recharge is simply the difference between precipitation inputs and evapotranspirative outputs.

Of these two quantities, precipitation has been well measured for many years. There exist rainfall records that date back many decades from daily recording stations, located in small towns and villages throughout the region (Bleed and Flowerday, 1998). With the exception of Burba et al. (1999) measured ET records however are non-existent. That study was limited to two growing seasons in a SandHills wetland.

Currently, the best estimates of ET from this region come from models that rely on remotely sensed data or from approximations made from standard meteorological information (Gosselin et al., 2006; Szilagyi et al., 2005; Chen and $\mathrm{Hu}, 2004$; Sridhar et al., 2006a). In the former case, the spatial resolution of the remote sensing images is often insufficient to differentiate between contrasting ecosystems. In the latter case, the location of the recording station is usually not optimal. Reporting meteorological stations are often located at small airports and towns which are usually sited on large, flat, dry valley floors (Bleed and Flowerday, 1998). While these locations may be adequate to quantify precipitation and local weather/climate, they will not sample all ecosystems and almost surely yield biased estimates of ET.

To explore the surface water balance and the functionality of these ecosystems, we installed three long-term experimental towers to directly measure precipitation and evapotranspiration at representative locations. These systems employed the Energy Balance/Bowen Ratio (EBBR) method (Fritschen, 1966; Dugas et al., 1991) to measure ET; other sensors were also included to assess data quality and to quantify precipitation.

\section{Site description}

The experiment was located at the University of Nebraska's Gudmundsen SandHills Research Laboratory near Whitman, Nebraska $\left(42^{\circ} \mathrm{O}^{\prime} \mathrm{N}, 101^{\circ} 28^{\prime} \mathrm{W}, 1085 \mathrm{~m}\right.$ elev. above mean sea level) (Figure 1). This facility is a production-scale research ranch located in the middle of the SandHills and spans almost $52 \mathrm{~km}^{2}$ with representative examples of each of the main ecosystem types (subirrigated meadow, dry valley, and dunal uplands). The region is classified as semi-arid with mean annual precipitation of $455 \mathrm{~mm}_{\text {year }}{ }^{-1}$ (Gosselin et al., 2006). The mean annual temperature is about $10{ }^{\circ} \mathrm{C}$ with maximum and minimum values of about $+40{ }^{\circ} \mathrm{C}$ and $-30{ }^{\circ} \mathrm{C}$ (Bleed and Flowerday, 1998). The first two stations were installed and became operational in 2002 in a subirrigated meadow and a dry valley floor. In 2003, the third site was installed on a dunal upland. The subirrigated meadow contains a mix of $\mathrm{C}_{3}$ and $\mathrm{C}_{4}$ warm and cool season perennial grasses and sedges. There is also a small population of introduced species including clovers. This site is annually harvested for hay production, usually in July or August. The dry valley site has similar vegetation except with a higher percentage of $C$ species. This site is lightly grazed and is not harvested for hay. The dunal uplands consist of almost all $\mathrm{C}_{4}$ grasses with some forbs and CAM species mixed in. Stem densities are highest in the subirrigated meadow and lowest at the upland site (Pool, 1914). The uplands and the dry valley soils are classified as Valentine Fine sands. 


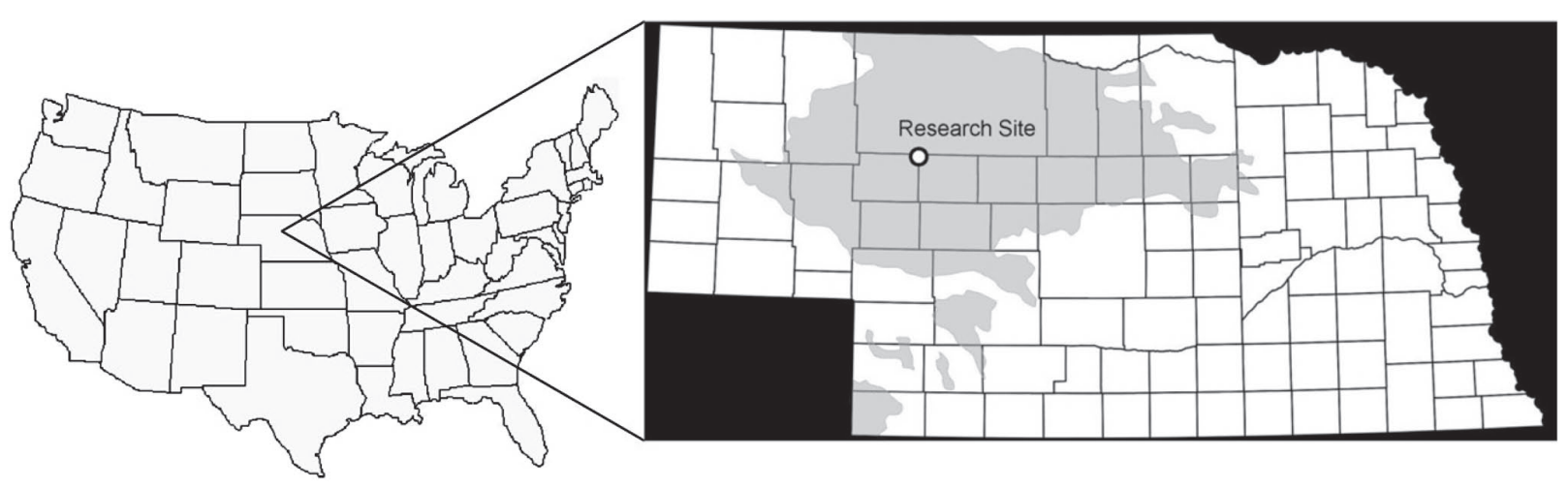

Figure 1. Location of the study site and the SandHills within the state of Nebraska.

This same soil type also underlies the subirrigated meadow; however there is a shallow layer (several centimeters) of organic material on top. Because of the relatively high hydraulic conductivity of sands, drainage is expected to be highest in the upland soils and lowest at the subirrigated meadow. All three stations are located within $10 \mathrm{~km}$ of each other and thus share a common climate. Additionally, in 2004, NOAA installed a National Climate Reference Network (NCRN) station (NOAA) with redundant, precision rain/snow gauges about $2 \mathrm{~km}$ south of our subirrigated meadow site. This provided valuable gap-filling data and additional quality control for our precipitation measurements. For this analysis, we have used seven years of data (20032009) that represent a variety of precipitation regimes, ranging from a very dry, drought year in 2006 to a very wet year in 2009.

\section{Methods}

The Energy balance/Bowen ratio (EBBR) method was used to measure water vapor and energy fluxes for this experiment (Fritschen, 1966; Dugas et al., 1991). It was chosen for its economy and its low maintenance and power requirements. Each tower consisted of identical temperature/relative humidity (T/RH) sensors (Humitter 5oY, Vaisala Oyj, Vantaa, Finland) mounted at approximately $3.9 \mathrm{~m}$ and $2.5 \mathrm{~m}$ above ground level, and housed in non-aspirated, 6-plate radiation shields (Radiation and Energy Balance Systems, Seattle, WA). In addition, a net radiometer (NR-lite, Kipp\&Zonen Inc., Delft, The Netherlands) (mounted $2.2 \mathrm{~m}$ above the surface) and two soil heat flux plates (model HFT-3, Radiation and Energy Balance Systems, Seattle, WA) (buried approximately $5 \mathrm{~cm}$ below the surface) were used to measure the components needed to calculate the available energy. To measure precipitation, a tipping bucket rain gauge (model TR-525 mm, Texas Electronics, Dallas, TX) was located next to the main instrument tower. Also included were a barometer (model PT1oıB, Vaisala, Oyj, Vantaa, Finland), a cup anemometer (model o14A, Met One Instruments, Inc., Grants Pass, OR), and a wind vane (model 024A, Met One Instruments, Inc., Grants Pass, OR). The anemometer and wind vane were mounted at the same height (approximately $3.9 \mathrm{~m}$ ) as the upper $\mathrm{T} / \mathrm{RH}$ sensor. The instruments were connected to a small data logger (CR23X, Campbell Scientific, Logan, UT) and were read once per second. 30 min averages were computed and stored on the data logger. These data were downloaded every one or two months during site maintenance visits. The systems were powered by $50 \mathrm{~W}$ solar panels charging deep-cycle RV/Marine batteries.

While snow fall in the region can account for up to $10 \%$ of the annual precipitation, our rain gauges were not equipped with melting heaters to measure it. We can only assume that some unknown fraction of snowfall accumulated in our gauges, melted, and was recorded, and that we do not have an accurate measurement of the total snowfall component. The NCRN gauges, on the other hand, are equipped to accurately measure snow. Comparison between our values and those at the NCRN station suggest that we did indeed capture most of the annual precipitation, but that we should include about a $10 \%$ uncertainty in our annual totals.

Due to power limitations at these remote sites, we were not able to include aspirator fans nor an exchanging mechanism with our $\mathrm{T} / \mathrm{RH}$ sensors. To compensate for inter-sensor biases in the temperature and relative humidity readings, we inter-calibrated all of them annually relative to an identical laboratory unit that was, itself, calibrated against a precision dew point hygrometer (model RHB-3, Omega Engineering, Inc, Stamford, CT) and a precision PRT thermometer (model PR-10, Omega Engineering, Inc., Stamford, CT). Over the period reported here, we found that annual sensor drift was minimal. To check the reliability of this EBBR method we co-located a high-quality eddy covariance flux system at our dry valley site to compare the latent and sensible heat fluxes obtained from the EBBR instruments. The eddy covariance system consisted of a sonic anemometer (model $\mathrm{R}_{3}$, Gill Instruments, Lymington, UK), a $\mathrm{CO}_{2} / \mathrm{H}_{2} \mathrm{O}$ Infrared Gas Analyzer (model LI-750o, LiCor Biosciences, Lincoln, $\mathrm{NE}$ ), and a small data collection computer. This system is almost identical to the one described by Billesbach et al. (2004). In Figure 2 , we show the energy budget closure for 30 min averages, obtained from the eddy covariance flux system for the entire year of 2007. We note that the energy budget from this system closed to within about $4 \%$. This is an indication that; there were no significant advective flows, that energy fluxes were representative of the area, that the system provided accurate and reliable

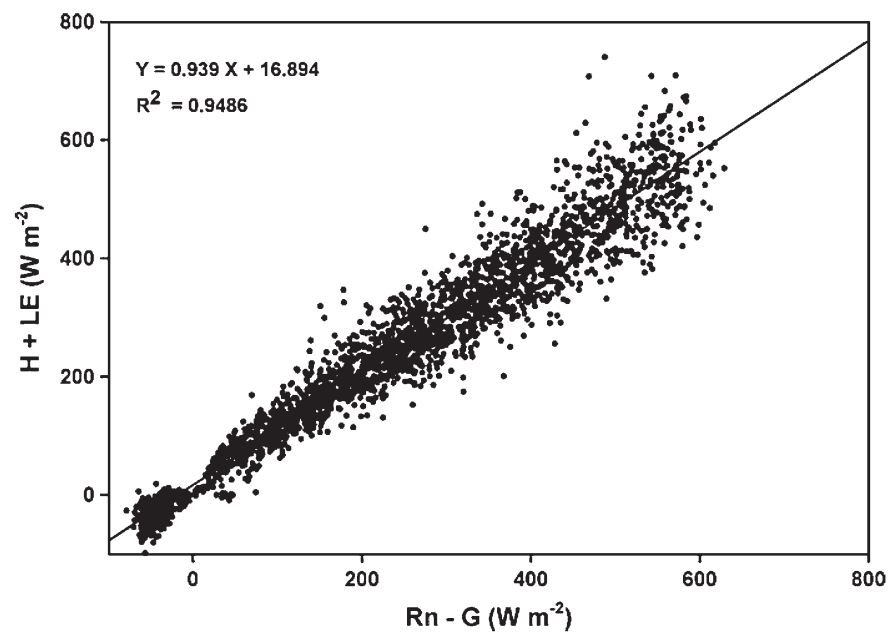

Figure 2. Energy closure for the co-located eddy covariance flux system at the dry valley site during 2007. The points represent half hourly averages, and the standard error of estimate for the regression was $41 \mathrm{~W} \mathrm{~m}^{-2}$. 


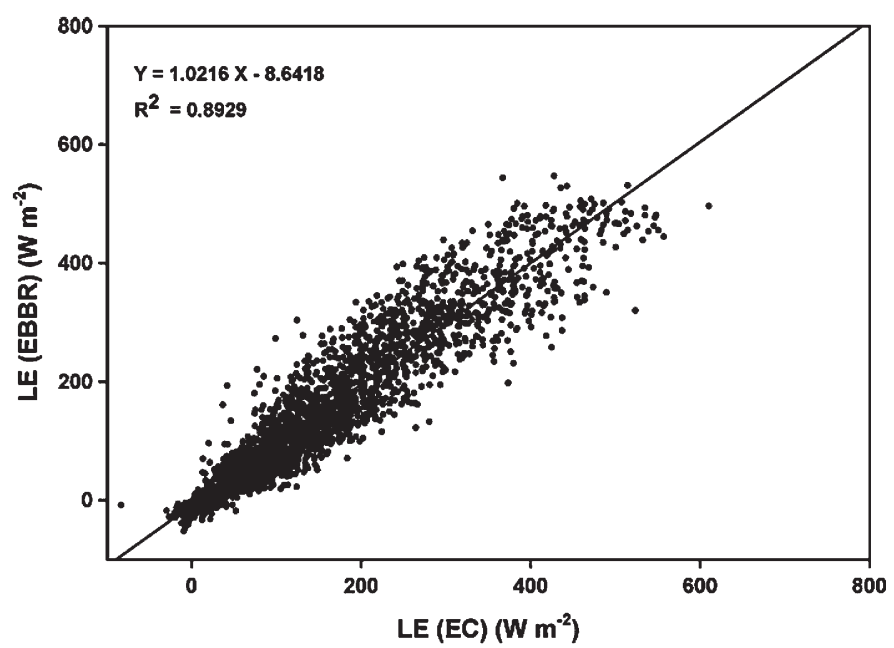

Figure 3. Comparison of latent heat fluxes obtained with the EBBR and eddy covariance flux systems at the dry valley site during 2007. The points represent half hourly averages, and the standard error of estimate was $44 \mathrm{~W} \mathrm{~m}^{-2}$.

values of sensible and latent heat fluxes, and that instrument drifts on sub-annual time scales were minimal. In Figure 3, we show the comparison of latent heat fluxes, also obtained over the entire year of 2007 between the EBBR and eddy covariance systems. Again, the agreement is quite good, with the EBBR values being only about $2 \%$ lower than the reference eddy covariance system. This comparison shows that our EBBR instrumentation and calibration method yields reliable and accurate latent heat fluxes which form the basis for calculating ET.

In our laboratory, the raw EBBR data were examined by an automated program that flagged bad and suspicious values. This process consisted of comparing the individual 30-min average data values to reasonable maximum and minimum values. ET values (and other quantities) were then calculated for each half hour interval and these were again quality checked.

We filled short gaps ( $2 \mathrm{~h}$ or less) in our half-hourly ET records with a linear interpolation from the preceding and post-ceding good data points. Daily sums were calculated from this intermediate data set. Gaps of several days were further filled, again using a linear interpolation scheme similar to the half-hourly gap filling algorithm. Over the 7 years considered in our analysis, between $25 \%$ and $30 \%$ of the original half hourly data were deemed unsuitable for various reasons. Daily, these bad points mostly occurred during the night, and seasonally, they mostly occurred during winter. The winter data loss has been attributed mostly to power problems and lack of system maintenance (due to infrequent site visits). Fortunately, the winter season contributed least to both precipitation and ET, and we assume that any systematic biases in our data were minimal. Annual sums were calculated from this gap filled data set. For precipitation records, the other sites and the NCRN data were used to fill in gaps in a similar manner.

Upon consideration of our calibration records and the intercomparison of our EBBR and eddy covariance systems, we find that the over-all accuracy of our EBBR data is better than $10 \%$. On the other hand, the scatter in the intercomparison of half hourly data suggests that the uncertainty (or lack of precision) of the individual measurements is larger. Conservatively, we estimate that our total measured ET uncertainties are roughly $10 \%$. In addition, the gap filling process further adds to this uncertainty. Overall, we have adopted a value of $15 \%$ for the uncertainty in our annual ET estimates and $10 \%$ for our annual precipitation values.

\section{Results and discussion}

The experimental sites experienced a wide variety of annual rainfall totals that span a factor of almost two (Figure 4a). Mean annual precipitation between 1983 and 2002 for this region was $455 \mathrm{~mm}$ (Gosselin et al., 2006) and is indicated by a solid line in Figure 4a. We therefore sampled years of below (2006), average (2007), and above average (2009) precipitation. Figure $4 \mathrm{~b}$ shows that ET was consistently greater in the subirrigated meadow than at either the dry valley floor or the uplands. Annual ET values from the dry valley and the dunal upland compare well with the range of 266-391 $\mathrm{mm}_{\text {year }}{ }^{-1}$ measured by Ryu et al. (2008) in a California grassland, under a Mediterranean climate while the values for the subirrigated meadow are similar to ones measured by Moreo et al. (2001) for an aquifer discharge grassland in the southwest U.S. In Figure 4c, we note that the subirrigated meadow was a consistent consumer of ground water (negative recharge values) while the uplands were a consistent recharge source (positive recharge values). Recharge at the dry valley site was intermediate with positive values in some years (e.g., the above average precipitation year of 2009) and negative values in others (e.g., the dry year of 2006).

While the year-to-year changes in annual precipitation were large, they were fairly uniform over the three sites (Figure 5a). At the upland site, a relatively constant fraction (ca. $0.45^{-0.6)}$ of the precipitation was returned to the atmosphere as ET (Figure 5 b). The exception to this was the apparently anomalous year of 2008 where 0.83 of the annual precipitation was returned to the atmosphere. The year to year change in annual ET (Figure 5c) was comparatively small $(-13 \%$ to $+25 \%)$ at the subirrigated meadow. By contrast, at the dry valley, interannual changes in ET ranged from $-47 \%$ to $+43 \%$ and from $-29 \%$ to $+103 \%$ at the upland site. The large range of values from the dry valley and the uplands more closely followed the annual change in precipitation than did the change in ET from the subirrigated meadow and suggest that ET in the subirrigated meadow was largely decoupled from annual precipitation. At the upland site, on the other hand, ET appears to be much more tightly controlled by precipitation. The upland site was a consistent source of ground water (positive recharge values), retaining on average, 0.47 of annual precipitation (excluding the apparently anomalous year of 2008 , Figure 5 d) and that the subirrigated meadow was a consistent sink of ground water (negative recharge values). The behavior of the dry valley site was intermediate between the other two; it behaved either as a source or a sink of atmospheric water (Figure $5 \mathrm{~b}$ and $5 \mathrm{~d}$ ). This suggests that, considering these three ecosystems, subirrigated meadows and dunal uplands are endpoints (or near endpoints) in a range of ecosystems that coexist in the SandHills, exhibiting distinct ecohydrologic behaviors.

To estimate annual aquifer recharge at the Gudmundsen ranch, we have summed the annual ecosystem recharge values (Figure 4c), weighted by the regional land cover fraction of the particular ecosystem (Rundquist, 1983; Gosselin et al., 2006). These sums represent the mean annual recharge for any point within the study area (assuming that the regional land cover fractions are valid for the ranch) (Table 1). Over the 6 year record, our data suggest that the aggregate land surface of the Gudmundsen ranch area contributed on average $115 \pm 20 \mathrm{~mm}$ year $^{-1}$ to aquifer recharge. There was positive recharge to the aquifer in all years including dry years (such as 2006). The majority of the recharge comes from dunal uplands due to the positive recharge values in all years as well as the fact that dunal uplands represent a majority of all land cover types in the region. The subirrigated meadow was a consistently large drain on the aquifer; however its small spatial extent limited its overall influence on regional recharge.

In general, the amounts of recharge reflect the trend in precipitation. This behavior is expected since ET in the dominant 

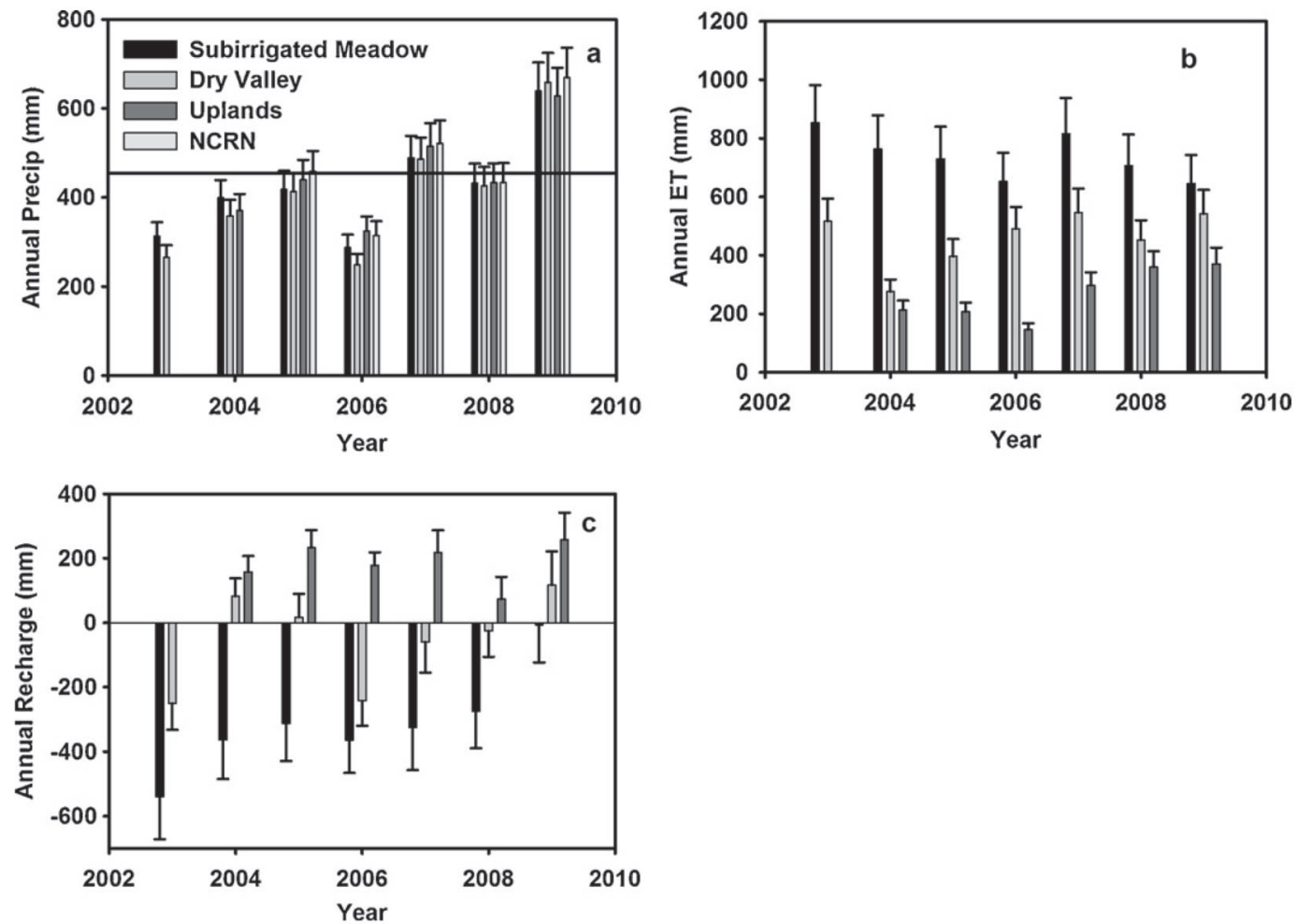

Figure 4. Precipitation (a), evapotranspiration (b), and recharge (c) for all sites and years of the study (all values in mm). In panel a, the horizontal line indicates the mean annual precipitation $(455 \mathrm{~mm}$ ) between 1983 and 2002. Also shown in panel a, is the annual precipitation recorded at the NOAA National Climate Reference Network (NCRN) station at the Gudmundsen ranch.
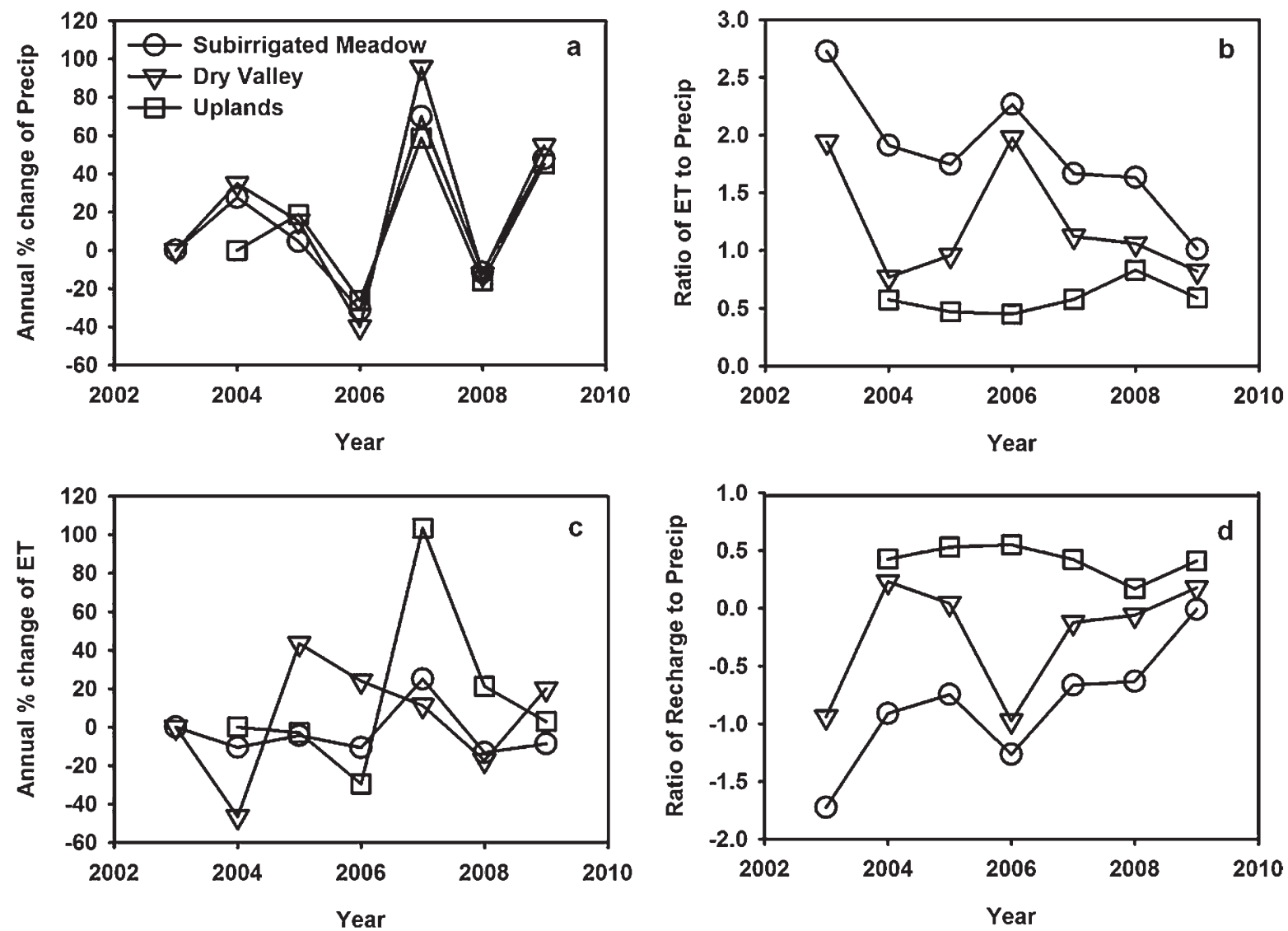

Figure 5. Percent change (year-to-year) of annual precipitation (a), ratio of evapotranspiration to precipitation (b), percent change (year-to-year) of annual evapotranspiration (c), and ratio of annual recharge to precipitation (d). 
ecosystem, dunal uplands (about $75 \%$ of the spatial extent), is tightly coupled to precipitation which implies that recharge will be too.

This attempt to estimate regional recharge suffers from two obvious shortcomings. First, our data have omitted lakes and wetlands. If we assume that their water fluxes are similar to those from subirrigated meadows, and using a regional spatial scaling factor of $2 \%$, we estimate that this omission will contribute an error of only $5 \mathrm{~mm}_{\text {year }}{ }^{-1}$ to $10 \mathrm{~mm}$ year-1 to our total. The second shortcoming is that our data represent essentially a point measurement in the regional context; however, as a first approximation, this analysis provides a useful starting point.

In 2008, the observed ratio of ET to precipitation at the uplands site was much higher than in other years. During July and August 2008 abnormally high amounts of precipitation and soil water contents were observed, especially at our upland site. This may have led to increased growth and transpiration of the $C_{4}$ grasses that dominate the uplands. Usually, these species are dormant during periods of high water stress that are typical of late summer. These unusual conditions however caused an abnormally high amount of ET during this period. Because these rains came late in the season when the grasses were relatively mature, there may have been more vegetation and a higher leaf area index available to utilize the water than during the, more typical, spring and early summer rains (when the plants were less fully developed). The carbon and water cycles are closely connected in this environment and the 2008 ET anomaly highlights the possible effects that precipitation timing can have on water balance and recharge.

\section{Conclusions}

In the Nebraska SandHills, subirrigated meadows and dunal uplands behave quite differently in terms of their ecohydrology. Dry valley floors exhibit characteristics of both of the other ecosystems. In the ecosystems studied, the availability of water, as determined by their positions relative to the water table and interannual variability in precipitation, is critical determinants of their hydrologic characteristics. These behaviors are also consistent with the vegetation in each of these three ecosystems. The mean recharge rate at the Gudmundsen SandHills Research Laboratory for our 6 year record was estimated to be $115 \pm 20 \mathrm{~mm}$ year $^{-1}$. This value falls within the bounds of model estimates that range over two orders of magnitude, from $1.3 \mathrm{~mm}$ year $^{-1}$ to $152 \mathrm{~mm}$ year $^{-1}$ for Kansas and Nebraska (USGS, 1997) but is somewhat larger than the $25 \mathrm{~mm}$ year $^{-1}$ estimated specifically for the SandHills as reported by Bleed and Flowerday (1998). Our value is, however almost identical to the one obtained by Szilagyi et al. (2011) who used ET estimates from MODIS data to do a similar estimation of recharge. We must caution, however that they (Szilagyi et al., 2011) used our ET data to calibrate their model.

Integrating our value over the entire region gives a total annual recharge volume of about $5.75 \mathrm{~km}^{3}$ year $^{-1}$. Comparing this to the estimated $10.25 \mathrm{~km}^{3}$ year $^{-1}$ of aquifer irrigation withdrawals for all of Nebraska (Hutson et al., 2005), we conclude that if our measured recharge rate is regionally representative, the aquifer will not be a sustainable resource at its current usage rate.

Our data suggests that the SandHills as a whole appears to be a consistent recharge source to the High Plains aquifer, but we must reiterate that the ET, precipitation, and recharge values reported here are specific to the Gudmundsen ranch. While they may be only approximately representative of the region, they are however a starting point in understanding the role of the SandHills in aquifer recharge and we hope that they will be refined by future studies. Accurate knowledge of the overall withdrawal and recharge rates for this resource are vital to responsible stewardship and for the future of sustainable agriculture in the Great Plains.
Table 1. Annual values of recharge $\left(\mathrm{mm} \mathrm{yr}^{-1}\right)$ for each ecosystem, scaled by the fractional coverage of that ecosystem and their totals $\left(\mathrm{mm} \mathrm{yr}^{-1}\right)$. Note that the fractional cover total only sums to $98 \%$ because we have no year-long data on the $2 \%$ of the land cover comprised of lakes and wetlands.

\begin{tabular}{|c|c|c|c|c|}
\hline Year & $\begin{array}{l}\text { Subirrigated } \\
\text { meadow } \\
\left(\mathrm{mm} \text { year }^{-1}\right)\end{array}$ & $\begin{array}{l}\text { Dry valley } \\
\left(\mathrm{mm}^{2} \text { year }^{-1}\right)\end{array}$ & $\begin{array}{l}\text { Uplands } \\
\left(\mathrm{mm}^{2} \text { year }^{-1}\right)\end{array}$ & $\begin{array}{l}\text { Total } \\
\left(\mathrm{mm}^{2} \text { year }^{-1}\right)\end{array}$ \\
\hline Fraction & $8 \%$ & $15 \%$ & $75 \%$ & \\
\hline 2003 & $-44 \pm 11$ & $-38 \pm 12$ & & \\
\hline 2004 & $-29 \pm 10$ & $+12 \pm 8$ & $+118 \pm 37$ & $+101 \pm 39$ \\
\hline 2005 & $-25 \pm 9$ & $+3 \pm 11$ & $+175 \pm 41$ & $+153 \pm 43$ \\
\hline 2006 & $-29 \pm 8$ & $-36 \pm 12$ & $+134 \pm 29$ & $+69 \pm 32$ \\
\hline 2007 & $-26 \pm 11$ & $-9 \pm 14$ & $+164 \pm 51$ & $+129 \pm 54$ \\
\hline 2008 & $-22 \pm 9$ & $-4 \pm 12$ & $+55 \pm 52$ & $+29 \pm 54$ \\
\hline 2009 & $-1 \pm 9$ & $+18 \pm 16$ & $+193 \pm 63$ & $+210 \pm 66$ \\
\hline Mean (6 year) & $-22 \pm 4$ & $-3 \pm 5$ & $+140 \pm 19$ & $+115 \pm 20$ \\
\hline
\end{tabular}

\section{References}

Billesbach, D. P., Fischer, M. L., Torn, M. S., Berry, J. A., 2004. A portable Eddy covariance system for the measurement of ecosystem-atmosphere exchange of $\mathrm{CO}_{2}$, water vapor, and energy. J. Atmos. Oceanic Technol. 21, 639-650.

Bleed, A. S., Flowerday, C. A. (eds.), 1998. An Atlas of the SandHills. Conservation and Survey Division. University of $\mathrm{Ne}-$ braska, Lincoln, NE.

Burba, G. G., Verma, S. B., Kim, J., 1999. Surface energy fluxes of an open water area in a mid-latitude Prairie Wetland. Boundary-Layer Meteorol. 91, 31-52.

Chen, X., Chen, Xi, 2004. Simulating the effects of reduced precipitation on ground water and stream flow in the Nebraska SandHills. J. Am. Water Resour Assn. 40, 419-430.

Chen, X., Hu, Q., 2004. Groundwater influences on soil moisture and surface evaporation. J. Hydrol. 297, 285-300.

Clarke, R. (Ed.), 20oo. United Nations Environmental Outlook 200o. Earthscan Publications, London.

Dugas, W. A., Fritschen, L. J., Gay, L. W., Held, A. A., Matthias, A. D., Reicosky, D. C., Steduto, P., Steiner, J. L., 1991. Bowen ratio, Eddy correlation, and portable chamber measurements of sensible and latent heat flux over irrigated spring wheat. Agric. Forest Meteorol. 56, 1-20.

Fritschen, L. J., 1966. Evapotranspiration rates of field crops determined by the Bowen ratio method. Agron. J. 58, 339-342.

Gosselin, D. C., Sridhar, V., Harvey, F. E., Goeke, J. W., 2006. Hydrological effects and groundwater fluctuations in interdunal environments in the Nebraska SandHills. Great Plains Res. 16, 17-28.

Healey, N. C., Irmak, Allen, R., Kjaersgaard, J., Arkebauer, T. J., Billesbach, D. P., Lenters, J. D., and Hubbard, K. G., 2012. Remote sensing and in situ based estimates of evapotranspiration for subirrigated meadow, dry valley, and upland dune ecosystems in the semi-arid SandHills of Nebraska, USA. Irr. Drainage Syst., doi: 10. 1007/s10795-011-9118-x, in press.

Hutson, S. S., Barber, N. L., Kenny, J. F., Linsey, K. S., Lumia, D. S., and Maupin, M. A., 2005. Estimated Use of Water in the United States in 2000. USGS Circular 1268.

McMahon, G., Thorson, T. D., Freeouf, J. A., Rorick, A. H., Keys, J. E., Gregonis, S. M., 2001. Waltman, S. W., and Omernick, J. M., Developing a Spatial Framework of Common Ecological Regions for the Conterminous United States. Environmental Management 28, 293.

Moreo, M. T., Laczniak, R. J., Stannard, D. I., 2001. Evapotranspiration Rate Measurements of Vegetation Typical of 
Ground-Water Discharge Areas in the Basin and Range Carbonate-Rock Aquifer System, Nevada and Utah, September 2005-August 2006. USGS Scientific Investigation Report 2007-5078.

NOAA, National Oceanic and Atmospheric Administration, U. S. Climate Reference Network website: http://www.ncdc. noaa.gov/crn/, in press.

Nativ, R., 1992. Recharge into Southern High Plains aquifer Possible mechanisms, unresolved questions. Environ. Geol. Water Sci. 19, 21-32.

Omernick, J. M., 1987. Ecoregions of the conterminous United States. Ann. Assoc. Am. Geographers 77, 118-125.

Pool, R. J., 1914. A study of the vegetation of the SandHills of Nebraska. Minnesota Bot. Stud. 4, 189-312.

Rundquist, D. C., 1983. Wetland inventories of Nebraska's Sandhills. Resource Report No. 9. Conservation and Survey Division, University of Nebraska-Lincoln.

Ryu, Y., Baldocchi, D. D., Ma, S., Hehn, T., 2008. Interannual variability of evapotranspiration and energy exchange over an annual grassland in California. J. Geophys. Res., doi: 10. 1029/2007JDoog263.
Sridhar, V., Hubbard, K. G., Wedin, D. A., 2006a. Assessment of soil moisture dynamics of the Nebraska Sandhills using longterm measurements and a hydrology model. J. Irr. Drainage Eng. 132 (463), 5, doi: 10. 1061/(ASCE) O733-9437

Sridhar, V., Loope, D. B., Swinehart, J. B., Mason, J. A., Oglesby, R. J., Rowe, C. M., 20o6b. Large wind shift on the Great Plains during the medieval warm period. Science 313, 345-347.

Szilagyi, J., Harvey, F. E., Ayers, J. F., 2005. Regional estimation of total recharge to ground water in Nebraska. Ground Water $43,63-69$.

Szilagyi, J., Zlotnik, V. A., Gates, J. B., Jozsa, J., 2011. Mapping mean annual groundwater recharge in the Nebraska Sand Hills, USA. Hydrol. J., doi: 10. 1007/s10040-011-0769-3.

USGS. 1997. Groundwater Atlas of the United States, HA-73oD. (United States Geological Survey).

Weeks, J. B., Gutentag, E. D., 1989. The High Plains regional aquifer-geohydrology in aquifers of the Midwestern area. In: Regional Aquifer Systems of the United States, American Water Resources Association Monograph Series No. 13. L. A. Swain and A. I. Johnson, Bethesda MD. 